\title{
Structural and functional changes in the central nervous system in the course of anorexia nervosa
}

\author{
Strukturalne i funkcjonalne zmiany w ośrodkowym układzie nerwowym w przebiegu \\ jadłowstrętu psychicznego
}

\author{
Michał Hys ${ }^{1}$ BE, Nikodem Skoczeń ${ }^{2} \mathrm{AD}$, \\ Ewelina Soroka ${ }^{2} \mathrm{DE}$, Marcin Olajossy ${ }^{2} \mathrm{ADF}$
}

1.I Clinic of Anaesthesiology and Intensive Therapy with Clinical Paediatric Department, Medical University of Lublin 2. II Department of Psychiatry and Psychiatric Rehabilitation, Medical University of Lublin

\begin{abstract}
New achievements within structural and functional imaging of central nervous system offer a basis for better understanding of the mechanisms underlying many mental disorders. In everyday clinical practice, we encounter many difficulties in the therapy of eating disorders. They are caused by a complex psychopathological picture, varied grounds of the problems experienced by patients, often poor motivation for active participation in the treatment process, difficulties in communication between patients and therapeutic staff, and various biological conditions of eating disorders. In this paper, the latest reports on new concepts and methods of diagnosis and treatment of anorexia nervosa have been analyzed. The selection of the analyzed publications was based on the criteria taking into account the time of publication, the size of research cohorts, as well as the experience of research teams in the field of nutritional disorders, confirmed by the number of works and their citations. The work aims to spread current information on anorexia nervosa neurobiology that would allow for determining the brain regions involved in the regulation of food intake, and consequently that may be a potential place where neurobiochemical processes responsible for eating disorders occur. In addition, using modern methods of structural imaging, the authors want to show some of the morphometric variations, particularly within white matter, occurring in patients suffering from anorexia nervosa, as well as those evaluated with magnetoencephalography of processes associated with the neuronal processing of information related to food intake. For example as regards anorexia nervosa, it was possible to localize the areas associated with eating disorders and broaden our knowledge about the changes in these areas that cause and accompany the illness. The described in this paper research studies using diffusion MRI fiber tractography showed the presence of changes in the white matter pathways of the brain, especially in the corpus callosum, which indicate a reduced content of myelin. These changes probably reflect malnutrition, and directly represent the effect of lipid deficiency. This leads to a weakening of the structure, and even cell death. In addition, there are more and more reports that show the normal volume of brain cells in patients with long-term remission of anorexia. It was also shown that in patients in remission stage there are functional changes within the amygdala in response to a task not related symptomatologically with anorexia nervosa. The appearing in the scientific literature data stating that in patients with anorexia nervosa there is a reduced density of GFAP + cells of the hippocampus and increased expression of vimentin and nestin, is also worth noting.
\end{abstract}

Keywords: anorexia nervosa, neuroimaging, central nervous system, limbic system, deep brain stimulation, brain-derived neurotrophic factor

\begin{abstract}
Streszczenie
Nowe osiągnięcia w zakresie strukturalnego i funkcjonalnego obrazowania ośrodkowego układu nerwowego pozwoliły na lepsze poznanie mechanizmów leżących u podłoża wielu zaburzeń psychicznych. W codziennej praktyce klinicznej napotykamy wiele trudno ści w zakresie terapii zaburzeń odżywiania. Są one spowodowane złożonym obrazem psychopatologicznym, zróżnicowanym podłożem problemów, których doświadczają pacjenci, często słabą motywacją do aktywnego udziału w leczeniu, trudnościami w komunikacji pomiędzy pacjentami i personelem terapeutycznym, wreszcie różnorodnymi uwarunkowaniami biologicznymi zaburzeń odżywiania się. W niniejszej pracy analizie poddane zostały najnowsze doniesienia związane z nowymi koncepcjami oraz metodami diagnostyki i ter apii anoreksji psychicznej. Dobór analizowanych publikacji został oparty o kryteria uwzględniające czas wydania, liczebność grup badawczych, jak i doświadczenie zespołów badawczych w tematyce zaburzeń odżywiana potwierdzony liczbą prac oraz ich cytowań. Celem pracy jest upowszechnienie aktualnych informacji odnoszących się do neurobiologii anoreksji pozwalających na wyróżnienie okolic mózgu biorących udział w regulacji przyjmowania pokarmu, a co za tym idzie mogących stanowić potencjalne miejsce, gdzie zachodzą procesy neurobiochemiczne leżące u podłoża zaburzeń odżywiania się. Ponadto autorzy postawili sobie za cel przedstawienie niektórych dostrzegalnych dzięki nowoczesnym metodom obrazowania strukturalnego odmienności morfometrycznych szczególnie $\mathrm{w}$ obrębie istoty białej występujących u chorych na jadłowstręt psychiczny, a także ocenianych z zastosowaniem metody magnetoencefalografii procesów związanych $\mathrm{z}$ neuronalnym przetwarzaniem informacji związanych ze spożywaniem pokarmu. W odniesieniu do jadłowstrętu psychicznego udało się na przykład zlokalizować obszary związane z zaburzeniami łaknienia oraz
\end{abstract}

(C) 2017 Medical University of Lublin. This is an open access article distributed under the Creative Commons Attribution-NonComercial-No Derivs licence (http://creativecommons.org/licenses/by-nc-nd/3.0/) 
poszerzyć naszą wiedzę na temat zmian w tych obszarach leżących u podłoża oraz towarzyszących chorobie. Opisane w niniejszym artykule badania przeprowadzone przy pomocy dyfuzyjnej traktografii MRI wykazały obecność zmian w drogach istoty białej mózgu, szczególnie ciała modzelowatego, które wskazują na zmniejszoną zawartość mieliny. Zmiany te prawdopodobnie są wyrazem niedożywienia, a bezpośrednio stanowią efekt niedoboru lipidów. Dochodzi do osłabienia struktury, a nawet śmierci komórek. Ponadto uwagę przykuwają pojawiające się $\mathrm{w}$ coraz większej liczbie doniesienia świadczące o prawidłowej objętości komórek mózgu u pacjentów z długoletnią remisją anoreksji. Wykazano ponadto, że u pacjentek w stadium remisji mamy do czynienia ze zmianami funkcjonalnymi $\mathrm{w}$ obrębie ciała migdałowatego $\mathrm{w}$ odpowiedzi na zadanie nie związane symptomatologicznie $\mathrm{z}$ jadłowstrętem psychicznym. Warto podkreślić również pojawiające się w literaturze naukowej dane mówiące o tym, że u chorych z jadłowstrętem psychicznym mamy do czynienia ze zmniejszoną gęstością komórek GFAP+ hipokampa i zwiększoną ekspresją wimentyny oraz nestyny.

Słowa kluczowe: jadłowstręt psychiczny, neuroobrazowanie, ośrodkowy układ nerwowy, układ limbiczny, głęboka stymulacja mózgu, neurotroficzny czynnik pochodzenia mózgowego

\section{Structural neuroimaging in anorexia nervosa}

Neurobiology plays an increasingly important role in understanding the etiology and the clinical picture of anorexia nervosa (AN). In recent years, methods of functional and structural imaging of brain have been greatly improved, and consequently the areas associated with eating disorders could be distinguished and pathophysiological mechanisms could be better understood.

Structural changes in the brain in the course of anorexia have already been described, in particular the reduction in the volume of gray and white matter [1-3]. In 2015, Travis et al., compared the properties of white matter in adolescent girls with AN with their healthy peers. Tests were conducted using modern method of functional imaging of the brain - diffusion MRI tractography (nuclear magnetic resonance). Diffusion tensor imaging (DTI) is a magnetic resonance imaging method used in diffusion anisotropy analysis of the central nervous system. It allows for observing details of the anatomical structure of the white matter of the brain. Currently, this method is highly valued in neuroradiology, providing morphological markers of disease progression or response to treatment [29]. In the last 10-15 years research on imaging technology using magnetic resonance, has focused more on the phenomenon of diffusion in living tissues [30]. Graphic representation of diffusion by magnetic resonance imaging is a very good way of visualizing the structures of the neuronal tissue, and due to its noninvasive character $[30,31]$, it is excellent for evaluating the development of brain from birth to full biological maturity of man and in older age. Travis et al., in their research showed the changes in the white matter tracts of the brain, especially the corpus callosum, which indicate a reduced content of myelin. These changes probably result from malnutrition and directly from lipid deficiency. This leads to the weakening or even the death of the cells [4]. The authors indicated the need to design longitudinal studies that would evaluate the transformation of disease-related changes after eliminating conditions characteristic of malnutrition.

This need was met by European researchers, who published a paper on the changes in the white matter of teenagers with anorexia, being evaluated for a 2.5 -year longitudinal follow-up [5]. Using diffusion MRI they carried out observation in patients at the beginning of treatment, with the lowest registered BMI and after about 4 months of weight rehabilitation and showed partial regression of changes in the white matter volume. This is indicated by a positive trend of normalization of the microstructure of the brain in these patients. There are more and more reports confirming the correct volume of brain cells in patients with long-term remission of anorexia. Bang et al. published a study directed to the patients in whom for more than one year, there were no symptoms of eating disorders and found no evidence of significant differences in the gray matter of the brain compared to the age-matched control group [6]. In order to measure the volume of brain structures there was used a voxelbased morphometry, the software, compiling the images obtained using MRI. The focus was particularly on the anterior cingulate cortex and the supplementary motor area due to previous reports of significantly changed grey and white matter volumes in patients with anorexia [7-8].

\section{Neuronal processing of information related to food intake in anorexia nervosa-study using magnetoence- phalography (MEG)}

In order to study the processes related to the neuronal processing of information related to food intake, Godier et al. used the magnetoencephalography (MEG) method. Researchers examined a group of 13 women diagnosed with restriction-type anorexia nervosa, a group of 14 women recovered from the restriction- type of anorexia nervosa and 15 healthy women in the control group. MEG data was acquired whilst participants viewed highand low-calorie food pictures. Attention was assessed with a reaction time task and eye tracking. Time-series analysis suggested increased neural activity in response to both calorie conditions in the AN groups, consistent with an early behavioral attentional bias AB. The authors observed increased neuronal activity at the level of 150 $\mathrm{ms}$ in the group of patients in the active phase of the disease. Neuronal activity in the group of patients in the remission stage was at the normal level, however, for this group an increase in activity at $320 \mathrm{~ms}$ after stimulation 
was demonstrated. According to earlier studies, the source data and behavioral data obtained by the authors indicate the intensification of processes related to attention and cognitive control in response to food-related stimuli. This can trigger a mechanism for avoiding exposure to food-induced stimuli and limiting food intake. The results obtained in the remission group may reflect the reversal of this avoidance mechanism, while the data from the source space and behavioral data indicate an increase in the visual and cognitive processing of food-induced stimuli [21].

\section{Incorrect functioning of the limbic system in patients with AN}

Kaye W.H et al. [9] presented a hypothesis about the imbalance between cognitive control and the activity of neuronal pathways associated with emotions, which may play an important role in the pathophysiology of anorexia, and especially influence the ability to ignore a strong, physiological feeling of hunger. The feeling of hunger seems to be one of the strongest stimuli that control human activity. In patients suffering from anorexia nervosa, reducing the influence of such a very powerful, instinctive mechanism regulating behavior related to the search for and consumption of food is surprising. Lasse et al. [10] demonstrated in anorexia-recovered patients functional changes in the amygdala in response to a task not related symptomologically to anorexia nervosa. In these studies, a database of images with a misrepresented verbal description was used in contrast to emotional expression on actors' faces. In the study group, lower amygdala activation was observed in comparison with the control group. This confirms the association of disease etiology with changes in the functioning of the limbic system also in response to stimulation unrelated to the causes and symptoms of anorexia.

There is evidence of dysfunction of the brain areas involved in cognitive processes in the anterior cingulate and prefrontal cortex in patients with AN. Steinglass et al. [11] demonstrate that neuronal pathways associated with the development of habits differ significantly in patients compared to the control group. Behaviors aimed at weight loss as opposed to the physiological needs of food intake activate the mesolimbic reward system, which becomes one of the causes of chronic, treatment-resistant form of anorexia.

\section{Changes in the density of GFAP + cells in an animal model of anorexia nervosa}

Earlier studies have shown a reduction in hippocampal volume in patients with anorexia. Dehydrationinduced anorexia is an animal model that mimics the features of anorexia nervosa such as intensified weight loss associated with a voluntary reduction in food intake. The energy supply to the brain is mediated by astrocytes, but whether their density is compromised by anorexia is unknown [12]. The aim of the study conducted by ReyesHaro et al. was to determine the density of GFAP + cells in specific regions of the hippocampus (CA1, CA2, CA3 and in the dentate gyrus). For this purpose the researchers used the DIA model. The results show that the density of GFAP + cells was significantly reduced (by about 20\%) in all regions of the hippocampus, with the exception of CA1. In the DIA model, the researchers observed a significant reduction in GFAP + cell / nuclei ratio in the CA2 region (by $23 \%$ ) and in the dentate gyrus (by 48\%). GFAP + cell density reduction was associated with reduced expression of GFAP proteins. In addition, anorexia increased the expression of intermediate filaments vimentin and nestin. Anorexia increased the number of reactive astrocytes in CA2 region and in the dentate gyrus more than two-fold. As indicated by the data presented in patients with anorexia nervosa, we observe a reduced density of GFAP + hippocampal cells and increased vimentin and nestin expression [13].

\section{Saccadic eye movements in anorexia}

It has been proven that saccadic eye movement tasks have proven useful in our understanding of the neurobiology of some other psychiatric illnesses as they utilise known brain regions. A. Philipou et al. examined them in patients with anorexia nervosa using functional MRI [22]. They did not show significant differences compared to the control group, which may indicate the unchanged functioning of brain areas associated with saccade movements in AN (anterior and extra visual fields, anterior cingulate, dorsolateral lateral cortex). These results are inconsistent with most recent reports of disturbances in the functioning of certain brain structures in patients with anorexia. There is also a hypothesis about the potential role of GABA and the superior colliculus in the etiology of the disease, but it requires research directly addressing the issue.

\footnotetext{
Altered SPECT ${ }^{123}$ I-iomazenil binding in the cingulate cortex of children with anorexia nervosa

Nagamitsu et al. noted the correlation between ${ }^{123}$ Iiomazenil binding by cortical GABA receptors and clinical symptoms of anorexia in children [16]. Higher EAT-26 scores were significantly associated with lower GABA iomazenil-binding activity especially in the anterior cingulate cortex. It was also observed that after the weight gain a more pronounced inhibition of GABA in the posterior cingulate cortex may indicate a better cognitive control than during the period of malnutrition. These reports are consistent with a growing number of evidence about the possibility of using observations of changes in the functioning of these brain areas in predicting the results of the treatment of anorexia in children.
} 


\section{BDNF a biomarker of remission in anorexia nervosa?}

Phillips et al. in their study assessed the importance of brain-derived neurotrophic factor BDNF as a biomarker in weight-recovered individuals with a history of anorexia nervosa (AN). Study groups included women meeting criteria for AN remission and healthy female controls. Participants were in a normal weight range, free of current major psychiatric disorder, and free of medication. Self-ratings included eating disorder symptoms, depression and anxiety. Plasma BDNF levels were measured by enzyme linked immunoassay. Plasma BDNF levels were not significantly different for AN remission group and control group. Plasma BDNF levels were inversely correlated with anxiety ratings in controls $(p<0.02)$ but not in the AN remission group [15].

\section{Fear of gaining weight gives way to being slim in AN patients.}

Recent reports support the concept that the differentiated limbic reward system activation contribute to the etiology and the development of anorexia. J. Clarke et al. [17-19] assessed the characteristics of the cognitive, emotional and physiologic response toward disease-specific pictures of female body shapes, in adult AN patients compared with healthy control (HC) women. Frequency and amplitude of skin conductance response (SCR) in patients with $\mathrm{AN}$ and $\mathrm{HC}$ were registered during processing of stimuli of three weight categories (over-, under- and normal weight). SCR within AN patients was more frequent during processing of underweight stimuli compared with normal- and overweight stimuli. Basing on this it was concluded that a higher positive value of starvation, rather than more negative one of overweight, might more accurately define females with AN. Then the role of the Val66Met BDNF polymorphism as a potential intermediate factor was assessed. This protein is responsible for the growth, maturation and survival of the neurons in the brain regions responsible for controlling hunger, thirst and maintaining weight. The Met allele of the BDNF gene could partly mediate the higher reward value of starvation observed in AN.

\section{Biomarkers in the diagnosis and treatment of AN}

Diagnosis of AN is currently based solely on clinical medical history and on the detection of abnormalities using physical, psychopathological and behavioral studies. A.Cerasa et al. have pointed out to the need to identify biomarkers that will help in detecting, planning treatment and monitoring the course of the disease [14]. The researchers used computer learning systems (machine learning) that can differentiate patients diagnosed with eating disorders from healthy people. Using the algorithms that classify standard MRI images, biomarkers that could become supportive in clinical practice have been identified, especially in the differentiation of eating disorders phenotypes. This may be one of the promising new trends in alternative diagnosis of anorexia nervosa.

\section{Recurrent transcranial magnetic stimulation as a promising method of AN therapy}

Bartoldy et al. [21] planned a pilot clinical trial to help find and improve methods of therapy of anorexia nervosa resistant to conventional treatment. Currently, the effects of psychotherapy, pharmacotherapy are not satisfactory, especially in the case of serious and prolonged illness. For this reason, with the growing understanding of the neurological basis of eating disorders, more and more attention is focused on methods of treatment that are non-invasive and act directly on specific areas of the brain that do not function properly in patients with AN. One of these techniques is repetitive transcranial magnetic stimulation, which can stimulate or inhibit the activity of the cerebral cortex, depending on the frequency used. The transcranial magnetic stimulation (TMS) method is based on the application of Faraday's law of electromagnetic induction, which says that the change in the parameter, which is the current flowing in one coil, can cause due to the magnetic field, the flow of current through the other coil. TMS stimulates an induced current in the ionic environment, which is the nervous tissue. In 1985, Barker et al. constructed a sufficiently strong magnetic stimulator to be able to stimulate the motor areas of the cerebral cortex and induce systolic activity of the small muscles of the hands [32]. This was the beginning of an extremely intense development of TMS as a tool for studying brain function, neurophysiological research and possible application options for therapeutic purposes. The latter is associated with the use of TMS in the form of repetitive series of magnetic pulses (repetitive transcranial magnetic stimulation, rTMS). The division due to the frequency of the series of pulses allows for distinguishing rTMS with high $(>1 \mathrm{~Hz})$ or low $(\leq 1 \mathrm{~Hz})$ frequencies correspondingly increasing and decreasing the excitability of the cerebral cortex [33]. TMS in the form of repeated impulses is to induce longer lasting changes in brain function, which are the result of prolonged strengthening or long-term synaptic weakening [34]. The rTMS is a nonconvulsive method, applied topically and acting via neuronal circuits [35]. Stimulation of the dorsolateral side of the prefrontal cortex proved to be useful in the treatment of addictions, obsessive-compulsive disorders or depression. The planned randomized, controlled study conducted by Bartoldy et al. aimed to assess the effectiveness and tolerance of this method of therapy and to develop protocols that will be useful in its implementation in clinical practice. 


\section{Changes in the functioning of the brain and cog- nitive remediation therapy (CRT)}

Inefficient cognitive -behavioral flexibility is considered a significant neurocognitive trait marker involved in the picture of anorexia nervosa, and Cognitive Remediation Therapy (CRT) is a specific treatment targeting this cognitive style. Brockmeyer et al. conducted a pilot study to identify changes in brain function potentially associated with CRT in AN patients. The authors obtained data through a randomized, controlled trial. Twenty-four patients were evaluated before and after 30 CRT sessions or non-specific neurocognitive therapy (NNT). Voxel-wise analysis of images obtained by functional magnetic resonance was used. Brain activation was measured during inhibition of response and task switching. Although the results did not reach the level of significance, they provided initial support for the hypothesis that there is a CRT-related effect of increased brain activation in the prefrontal cortex, its dorsolateral, sensory-motor and temporal cortex during task switching [23].

\section{Conclusions}

New achievements in the field of structural and functional imaging of the central nervous system allowed for a better understanding of the mechanisms underlying many mental disorders. In relation to anorexia nervosa, areas related to eating disorders could be located and our knowledge about changes in these underlying areas and accompanying diseases could be broadened. There is a great need for further discoveries that will allow for determining biological factors favoring the disease, as well as substances that may constitute biomarkers, allowing for predicting the risk of disease and also to respond to treatment. Predicting sensitivity to treatment would facilitate shortening of the therapeutic process significantly, and thus would allow many patients to recover faster and return to proper functioning. Advances in neuroscience and biomedical engineering also give an opportunity to improve neuroimaging methods and implement new treatments.

\section{Neuroobrazowanie strukturalne $w$ jadłowstręcie psychicznym}

W zrozumieniu etiologii oraz obrazu klinicznego jadłowstrętu psychicznego (anorexia nervosa, AN) coraz większą rolę odgrywa neurobiologia. W ciągu ostatnich lat metody funkcjonalnego oraz strukturalnego obrazowania mózgu zostały znacznie udoskonalone, czego skutkiem jest wyodrębnienie obszarów powiązanych $\mathrm{z}$ zaburzeniami odżywiania się oraz lepsze poznanie ich patofizjologicznych mechanizmów.

Zmiany strukturalne mózgu w przebiegu anoreksji zostały już opisane, szczególnie zmniejszenie objętości istoty szarej i białej [1-3]. W 2015 roku Travis i wsp., porównali właściwości istoty białej u chorych dorastających dziewcząt z ich zdrowymi rówieśniczkami. Badania zostały przeprowadzone przy pomocy nowoczesnej metody obrazowania funkcjonalnego mózgu - dyfuzyjnej traktografii MRI (jądrowego rezonansu magnetycznego). Obrazowanie tensora dyfuzji (DTI) jest metodą rezonansu magnetycznego stosowaną $\mathrm{w}$ analizie dyfuzyjnej anizotropii w ośrodkowym układzie nerwowym. Pozwala ona zaobserwować szczegóły struktury anatomicznej istoty białej mózgu. Obecnie metoda ta jest bardzo ceniona w obszarze neuroradiologii, dostarczając morfologicznych markerów zaawansowania procesu chorobowego czy też reakcji na leczenie [29]. W okresie ostatnich 10-15 lat badania nad technologią obrazowania za pomocą rezonansu magnetycznego skupiły się bardziej na zjawisku dyfuzji w żywych tkankach [30]. Graficzne przedstawienie dyfuzji metodą badania rezonansu magnetycznego jest bardzo dobrym sposobem uwidaczniania struktur tkanki nerwowej, a przez swój nieinwazyjny charakter [30, 31], znakomicie nadaje się do oceny rozwijającego się mózgu od narodzin dziecka do pełnej dojrzałości biologicznej człowieka i wieku podeszłego. Travis i wsp. w swoich badaniach wykazali obecność zmian $\mathrm{w}$ drogach istoty białej mózgu, szczególnie ciała modzelowatego, które wskazują na zmniejszoną zawartość mieliny. Zmiany te powstają prawdopodobnie na skutek niedożywienia, a bezpośrednio z powodu niedoboru lipidów. Dochodzi do osłabienia, a nawet śmierci komórek [4]. Autorzy wskazali potrzebę zaprojektowania badań długoterminowych, które oceniłyby transformację powstałych $\mathrm{w}$ wyniku choroby zmian po wyeliminowaniu warunków charakterystycznych dla niedożywienia.

Na tę potrzebę postarali się odpowiedzieć europejscy badacze publikując pracę dotyczącą zmian $\mathrm{w}$ istocie białej mózgu u nastolatek z anoreksją, ocenianych w ramach 2,5-letniej obserwacji [5]. Prowadząc obserwacje przy pomocy dyfuzyjnego MRI u pacjentek na początku terapii, z najniższym zarejestrowanym BMI oraz po około 4 miesiącach wagowej rehabilitacji wykazali częściową regresję zmian w objętości substancji białej. Wskazuje to na korzystny trend normalizacji mikrostruktury mózgu w tej grupie chorych. Pojawia się coraz więcej doniesień świadczących o prawidłowej objętości komórek mózgu u pacjentów z długoletnią remisją anoreksji. Bang i wsp. opublikowali badanie ukierunkowane na chore, u których ponad rok nie wystąpiły objawy zaburzeń odżywiania i nie wykazali w nim znaczących różnic w ilości substancji szarej mózgu w porównaniu z wiekowo dobraną grupą kontrolną[6]. W celu zmierzenia objętości struktur mózgu 
posługiwano się morfometrią bazującą na wokselach, oprogramowaniem opracowującym obrazy uzyskane przy pomocy MRI. Skupiono się szczególnie na przedniej części zakrętu obręczy oraz dodatkowym polu ruchowym ze względu na wcześniejsze doniesienia o znacznie zmienionych objętościach substancji szarej i białej u chorych na anoreksję [7-8].

Neuronalne przetwarzanie informacji związanych z przyjmowaniem pokarmu $w$ jadłowstręcie psychicznym-badanie $\mathrm{z}$ zastosowaniem magnetoencefalografii (MEG)

Godier i wsp. w celu zbadania procesów związanych z neuronalnym przetwarzaniem informacji związanych ze spożywaniem pokarmu posłużyli się metodą magnetoencefalografii (MEG). Badacze przebadali grupę 13 kobiet $\mathrm{z}$ rozpoznaniem jadłowstrętu psychicznego typu restrykcyjnego, grupę 14 kobiet będących w srtanie remisji w przebiegu typu restrykcyjnego jadłowstrętu psychicznego i 15 kobiet zdrowych stanowiących grupę kontrolną. Dane magnetoencefalograficzne zostały zgromadzone podczas gdy osoby badane oglądały zdjęcia pokarmów o wysokiej i niskiej kaloryczności. Uwaga była oceniana dzięki zadaniom badającym czas reakcji, a także poprzez śledzenie ruchów gałek ocznych. Analiza szeregów czasowych wykazała zwiększenie aktywności neuronalnej w odpowiedzi zarówno na pokarmy o wysokiej jak i o niskiej kaloryczności w grupach pacjentek chorujących na jadłowstręt psychiczny, zgodne z wcześniej określoną stronniczością uwagi. Autorzy zaobserwowali zwiększoną aktywność neuronalną na poziomie $150 \mathrm{~ms}$ w grupie pacjentek w aktywnej fazie choroby. Aktywność neuronalna $\mathrm{w}$ grupie pacjentek $\mathrm{w}$ stadium remisji była na normalnym poziomie, jednak dla tej grupy wykazano wzrost aktywności na poziomie $320 \mathrm{~ms}$ po stymulacji. Zgodnie z wcześniejszymi badaniami, uzyskane przez autorów analizy przestrzeni źródłowej i dane behawioralne wskazują na nasilenie procesów związanych z uwagą i kontrolą poznawczą $\mathrm{w}$ odpowiedzi na bodźce związane ze spożywaniem pokarm w. Może to uruchamiać mechanizm unikania narażenia na bodźce związane ze spożywaniem pokarmu i ograniczanie przyjmowania pokarmu. Wyniki uzyskane $\mathrm{w}$ grupie pacjentek $\mathrm{w}$ stadium remisji mogą odzwierciedlać odwrócenie tego mechanizmu unikania, z kolei dane z przestrzeni źródłowej i dane behawioralne wskazują na wzmożenie procesów wizualnego i poznawczego przetwarzania bodźców związanych ze spożywaniem pokarmu [21].

\section{Nieprawidłowe funkcjonowanie układu limbicznego u chorych z AN}

Kaye W.H i wsp. [9] przedstawili hipotezę mówiącą o braku równowagi między kontrolą poznawczą a aktyw- nością szlaków neuronalnych związanych z emocjami, który może odgrywać istotną rolę w patofizjologii anoreksji, a szczególnie wpływać na umiejętność zignorowania silnego, fizjologicznego uczucia głodu. Uczucie głodu wydaje się być jednym z najsilniejszych bodźców zawiadujących aktywnością człowieka. U chorych cierpiących z powodu jadłowstrętu psychicznego zadziwia ograniczenie wpływu tego bardzo silnego, instynktownego mechanizmu regulującego zachowania związane z poszukiwaniem i spożywaniem pokarmu. Lasse i wsp. [10] wykazali $\mathrm{u}$ pacjentek $\mathrm{w}$ stanie remisji zmiany funkcjonalne $\mathrm{w}$ ciele migdałowatym $\mathrm{w}$ odpowiedzi na zadanie nie związane symptomatologicznie $\mathrm{z}$ jadłowstrętem psychicznym. W tych badaniach wykorzystano bazę zdjęć z błędnie dobranym opisem słownym w kontraście do ekspresji emocjonalnej na twarzy aktorów. W grupie badawczej uzyskano mniejszą aktywację jądra migdałowatego w porównaniu z grupą kontrolną. Potwierdza to powiązanie etiologii choroby ze zmianami w funkcjonowaniu układu limbicznego również $w$ odpowiedzi na stymulację niezwiązaną z przyczynami i objawami anoreksji.

Istnieją dowody na zaburzenia w zakresie obszarów mózgu związanych z procesami poznawczymi w przedniej części zakrętu obręczy oraz korze przedczołowej u chorych na AN . Steinglass i wsp.[11] dowodzą, że szlaki neuronalne powiązane $\mathrm{z}$ tworzeniem nawyków różnią się znacznie u pacjentów w porównaniu z grupą kontrolną. Zachowania służące utracie wagi pozostające w opozycji do fizjologicznej potrzeby dostarczania pokarmu aktywują mezolimbiczny układ nagrody, co staje się jedną z przyczyn przewlekłej, opornej na leczenie postaci anoreksji.

\section{Zmiany gęstości komórek GFAP+ w zwierzęcym mo- delu jadłowstrętu psychicznego}

Wcześniejsze badania wykazały zmniejszenie objętości hipokampa u pacjentów $\mathrm{z}$ anoreksją. Anoreksja indukowana odwodnieniem(Dehydration-induced anorexia) to zwierzęcy model naśladujący cechy jadłowstrętu psychicznego takie jak nasilona utrata wagi związana z dobrowolnym zmniejszeniem ilości przyjmowanego pokarmu. Energia przekazywana jest do mózgu za pośrednictwem astrocytów, jednak do tej pory nie wiadomo czy jadłowstręt psychiczny narusza gętość tych komórek[12]. Celem badania przeprowadzonego przez ReyesHaro i wsp. było określenie gęstości komórek GFAP + w określonych regionach hipokampa (CA1, CA2, CA3 oraz w zakręcie zębatym), w tym celu badacze posłuzyli się modelem DIA. Wyniki uzyskane przez tych autorów pokazują, że gęstość komórek GFAP + była znacznie obniżona (o około 20\%) we wszystkich regionach hipokampa, z wyjątkiem CA1.W modelu DIA badacze zaobserwowali znaczne zmniejszenie współczynnika komórki GFAP +/jądra komórkowe $\mathrm{w}$ regionie CA2 (o 23\%) oraz 
w zakręcie zębatym (o 48\%). Obniżenie gęstości komórek GFAP + było skojarzone w z obniżoną ekspresją białka GFAP. Dodatkowo, brak łaknienia zwiększył ekspresję pośrednich filamentów wimentyny oraz nestyny. Brak łaknienia zwiększał liczbę reaktywnych astrocytów $\mathrm{w}$ regionie CA2 oraz $\mathrm{w}$ zakręcie zębatym ponad dwukrotnie. Jak wskazują przedstawione dane u chorych z jadłowstrętem psychicznym mamy do czynienia ze zmniejszoną gęstością komórek GFAP+ hipokampa i zwiększoną ekspresją wimentyny oraz nestyny [13].

\section{Sakkadowe ruchy gałek ocznych w anoreksji}

Dowiedziono, że zadania wykorzystujące sakkadowe ruchy gałek ocznych są przydatne w lepszym zrozumieniu neurobiologicznych podstaw niektórych schorzeń psychiatrycznych ze względu na dobrze poznane mózgowe mechanizmy ich powstawania. A. Philipou i wsp. zbadali je u chorych na anoreksję psychiczną przy pomocy funkcjonalnego obrazowania MRI [22]. Nie wykazali znaczących różnic w porównaniu z grupą kontrolną, co może wskazywać na niezmienione funkcjonowanie obszarów mózgu związanych $\mathrm{z}$ ruchami sakkadowymi w AN(przednich i dodatkowych polach wzrokowych, przedniej części zakrętu obręczy, grzbietowo-bocznej części kory przedczołowej). Wyniki te nie są spójne z większością aktualnych doniesień dotyczących zaburzeń w funkcjonowaniu określonych struktur mózgu u chorych na anoreksję. W pracy została również wysunięta hipoteza o potencjalnej roli GABA oraz wzgórków czworaczych górnych w etiologii choroby, wymaga ona jednak badań bezpośrednio ukierunkowanych na dane zagadnienie.

\section{Zmienione wiązanie I $^{123}$ - iomazenilu $w$ korze obręczy u dzieci z anoreksją badane przy pomocy SPECT}

Nagamitsu i wsp. zwrócili uwagę na współzależność pomiędzy wiązaniem I ${ }^{123-i o m a z e n i l u ~ p r z e z ~ k o r o w e ~ r e c e p t o-~}$ ry GABA, a objawami klinicznymi anoreksji u dzieci [16]. Wyższe wyniki w teście EAT-26 oraz zaburzenia nastroju były mocno powiązane z mniejszym wiązaniem hamującym GABA w niektórych regionach mózgu, szczególnie przedniej części zakrętu obręczy. Zaobserwowano również, że po wzroście wagi bardziej nasilone hamowanie GABA w tylnej części zakrętu obręczy może wskazywać na lepszą niż w czasie okresu niedożywienia kontrolę kognitywną. Doniesienia te są spójne z rosnącą liczbą dowodów świadczących o możliwości wykorzystania obserwacji zmian w funkcjonowaniu tych obszarów mózgu w przewidywaniu wyników leczenia anoreksji u dzieci.

\section{BDNF biomarkerem remisji w przebiegu jadłowstrętu psychicznego?}

Phillips i wsp. w swoim badaniu oceniali znaczenie obecnego w osoczu mózgowopochodnego czynnika wzro- stu (BDNF) jako biomarkera u osób z dodatnim wywiadem w kierunku jadłowstrętu psychicznego, które powróciły do prawidłowej masy ciała. Autorzy objęli badaniem grupę kobiet spełniających kryteria remisji w przebiegu jadłowstrętu psychicznego i zdrowe kobiety z grupy kontrolnej. Masa ciała uczestników badania mieściła się w zakresie wartości prawidłowych, wykluczono występowanie u nich poważnych zaburzeń psychicznych i nie przyjmowali oni leków psychotropowych. Objawy zaburzeń odżywiania, depresji i lęku były charakteryzowane na zasadzie samooceny. Poziomy BDNF w osoczu mierzone były za pomocą enzymatycznego testu immunologicznego. Poziomy BDNF w osoczu nie różniły się znacząco miedzy grupami pacjentek w remisji i grupą kontrolną. Poziomy BDNF w osoczu okazały sie być ujemnie skorelowane $\mathrm{z}$ oceną nasilenia lęku $\mathrm{w}$ grupie kontrolnej $(\mathrm{p}<0,02)$, ale nie w grupie pacjentek w remisji [15].

\section{Strach przed przybraniem wagi ustępuje chęci bycia szczupłym u pacjentek z AN.}

Aktualne doniesienia wspierają koncepcję mówiącą o wpływie zróżnicowanej aktywacji limbicznego układu nagrody w etiologii oraz rozwoju anoreksji. J. Clarke i wsp. [17-19] zbadali przy pomocy zdjęć kobiet o zróżnicowanej budowie ciała z kognitywną oraz emocjonalną odpowiedzią u pacjentek z AN w porównaniu ze zdrową grupą kontrolną. Wyniki opracowane zostały na podstawie częstotliwości i amplitudy reakcji elektrodermalnej podczas prezentacji trzech grup obrazów - niedowagi, nadwagi oraz normalnej masy ciała. U pacjentek wykazano największą częstotliwość podczas projekcji zdjęć niedożywionych kobiet. Wywnioskowano na tej podstawie, że dla chorych na anoreksję wyższą wartość może mieć głodowanie, niż strach przed przybraniem wagi. Została również oceniona pośrednia rola polimorfizmu Val66Met BDNF. Białko to odpowiada za wzrost, dojrzewanie oraz przetrwanie neuronów w regionach mózgu odpowiedzialnych za kontrolę głodu, pragnienia oraz utrzymania masy ciała. Prawdopodobne jest, że allele Met genu kodującego BDNF mogą pośrednio wpływać na potrzebę głodzenia się u pacjentek z anoreksją psychiczną.

\section{Biomarkery w diagnozowaniu i leczeniu AN}

Diagnoza anoreksji psychicznej opiera się aktualnie wyłącznie na wywiadzie klinicznym oraz wykrywaniu nieprawidłowości przy pomocy fizycznych, psychopatologicznych oraz behawioralnych badań. A.Cerasa i wsp. zwrócili uwagę na potrzebę zidentyfikowania biomarkerów, które pomogłyby w wykrywaniu, planowaniu leczenia oraz monitorowaniu przebiegu choroby [14]. Badacze wykorzystali komputerowe systemy samouczące się (machine learning), które są w stanie różnicować pacjentów z diagnozą zaburzeń odżywiania od osób zdrowych. 
Przy użyciu algorytmów klasyfikujących standardowe obrazy MRI udało się wyodrębnić biomarkery mogące stać się wsparciem w praktyce klinicznej, szczególnie w różnicowaniu fenotypów zaburzeń odżywiania. Może być to jeden z obiecujących nowych trendów dotyczących alternatywnego diagnozowania anoreksji psychicznej.

\section{Powtarzalna przezczaszkowa stymulacja magnetycz- na jako obiecująca metoda terapii AN}

Bartoldy i wsp. [21] zaplanowali pilotażowe badanie kliniczne, które ma pomóc w znalezieniu oraz udoskonaleniu metod terapii anoreksji psychicznej opornej na leczenie konwencjonalne. Aktualnie efekty psychoterapii, czy farmakoterapii nie są zadowalające, szczególnie w przypadku poważnej i przedłużającej się choroby. $\mathrm{Z}$ tego powodu, przy rosnącym zrozumieniu neurologicznych podstaw zaburzeń odżywiania, coraz więcej uwagi skupiają metody leczenia, które są nieinwazyjne oraz działają bezpośrednio na określone obszary mózgu nie funkcjonujące prawidłowo u pacjentów z AN. Jedną z tych technik jest powtarzalna przezczaszkowa stymulacja magnetyczna, która może stymulować lub hamować aktywność kory mózgu,w zależności od użytej częstotliwości. Metoda przezczaszkowej stymulacji magnetycznej (transcranial magnetic stimulation, TMS) opiera się na zastosowania prawa indukcji elektromagnetycznej Faradaya, które mówi, że zmiana parametru jakim jest natężenie prądu płynącego w jednej cewce może wywołać poprzez oddziaływanie pola magnetycznego przepływ prądu w drugiej cewce. TMS wywołuje powstanie prądu indukowanego w środowisku jonowym, jakim jest tkanka nerwowa. Rok 1985, kiedy to Barker i wsp. skonstruowali wystarczająco silny stymulator magnetyczny, by był w stanie pobudzić pola ruchowe kory mózgowej i wywołać aktywność skurczową drobnych mięśni rąk [32]. Stało się to początkiem niezwykle intensywnego rozwoju TMS jako narzędzia do badania czynności mózgu, badań neurofizjologicznych i ewentualnych możliwości stosowania jej do celów terapeutycznych. To ostatnie wiąże się ze stosowaniem TMS w formie powtarzanych serii impulsów magnetycznych (repetitive transcranial magnetic stimulation, rTMS). Podział ze względu na częstotliwość serii impulsów pozwala wyróżnić rTMS o wysokiej (> $1 \mathrm{~Hz}$ ) albo niskiej ( $\leq 1 \mathrm{~Hz}$ ) częstotliwości odpowiednio zwiększającej i zmniejszającej pobudliwość kory mózgowej [33]. TMS w postaci powtarzanych impulsów ma wywoływać dłużej utrzymujące się zmiany w czynności mózgu, które są wynikiem długotrwałego wzmocnienia lub długotrwałego osłabienia synaptycznego [34]. rTMS to metoda niedrgawkowa, aplikowana miejscowo i działającą poprzez obwody neuronalne [35]. Stymulacja grzbietowo-bocznej części kory przedczołowej okazała się przydatna w leczeniu uzależnień, zaburzeń obsesyjno-kompulsyjnych, czy depresji.
Zaplanowane randomizowane, kontrolowane badanie, które przeprowadzili Bartoldy i wsp. miało na celu ocenienie efektywności i tolerancji tej metody terapii oraz opracowanie protokołów, które będą przydatne we wdrożeniu jej do praktyki klinicznej.

\section{Zmiany w funkcjonowaniu mózgu a terapia uspraw- niana poznawczego (CRT)}

Słaba elastyczność poznawczo-behawioralna jest uważana za znaczącą cechę w obrazie jadłowstrętu psychicznego, w którego leczeniu poprawę uzyskuje sie między innymi poprzez terapię usprawnienia poznawczego (CRT). Brockmeyer i wsp. przeprowadzili badanie pilotażowe mające na celu zidentyfikowanie zmian w funkcjonowaniu mózgu potencjalnie związanych z CRT u pacjentów chorujących na jadłowstręt psychiczny. Autorzy uzyskali dane na drodze randomizowanego, kontrolowanego badania. Dwudziestu czterech pacjentów oceniano przed i po 30 sesjach CRT lub niespecyficznych terapii neuropoznawczych. Zastosowano analizę typu voxel-wise obrazów uzyskanych metodą funkcjonalnego rezonansu magnetycznego. Aktywacja mózgu mierzona była podczas hamowania odpowiedzi i przełączania zadań. Chociaż wyniki nie osiągnęły poziomu istotności, dostarczają wstępnego wsparcia hipotezy, że istnieje związany z CRT efekt wzrostu aktywacji mózgu w korze przedczołowej, w jej części grzbietowo-bocznej, korze czuciowo-ruchowej i skroniowej podczas przełączania zadań [23].

\section{Podsumowanie}

Nowe osiągnięcia w zakresie strukturalnego i funkcjonalnego obrazowania ośrodkowego układu nerwowego pozwoliły na lepsze poznanie mechanizmów leżących u podłoża wielu zaburzeń psychicznych. $\mathrm{W}$ odniesieniu do jadłowstrętu psychicznego udało się między innymi zlokalizować obszary związane z zaburzeniami odżywiania się oraz poszerzyć naszą wiedzę na temat zmian w tych obszarach leżących u podłoża oraz towarzyszących temu schorzeniu. Istnieje ogromna potrzeba dalszych odkryć, które pozwolą na ustalenie biologicznych czynników sprzyjających zachorowaniu, a także substancji mogących stanowić biomarkery pozwalającę na przewidywanie ryzyka zachorowania, a także odpowiedzi na leczenie. Przewidywanie wrażliwości na leczenie pozwoliło by znacznie skrócić proces terapeutyczny, a tym samym umożliwić wielu chorym szybszy powrót do zdrowia i prawidłowego funkcjonowania. Postępy w zakresie neurobiologii oraz inżynierii biomedycznej dają także szansę na doskonalenie metod neuroobrazowania i wdrożenie nowych metod leczenia.

\section{Conflict of interest}

The authors have declared no conflict of interest. 


\section{References:}

1. Boghi A., Sterpone S., Sales S., D'Agata F., Bradac G.B., Zullo G., et al. In vivo evidence of global and focal brain alterations in anorexia nervosa. Psychiatry Res., 2011; 192: 154-159; DOI: 10.1016/j.pscychresns.2010.12.008.

2. Muhlau M., Gaser C., Ilg R., Conrad B., Leibl C., Cebulla M.H., et al. Gray matter decrease of the anterior cingulate cortex in anorexia nervosa. Am. J. Psychiatr., 2007; 64: 1850-1857; DOI: 10.1176/appi.ajp.2007.06111861.

3. Swayze VW., Andersen AE., Andreasen NC., Arndt S., Sato Y., Ziebell S. Brain tissue volume segmentation in patients with anorexia nervosa before and after weight normalization. Int J Eat Disord., 2003; 33(1): 33 - 44; DOI http://dx.doi.org/10.1002/ eat.10111.

4. Travis K., Golden N., Feldman H., Solomon M., Nguyen J., Mezer A., Yeatman J., Dougherty R. Abnormal white matter properties in adolescent girls with anorexia nervosa. Neuroimage Clin., 2015; 9: 648-659; DOI http://dx.doi.org/10.1016/j.nicl.2015.10.008.

5. Vogel K., Timmers I., Kumar V., Nickl-Jockschat T., Bastiani M., Roebroek A., Herpertz-Dahlmann B., Konrad K., Goebel R., Seitz J. White matter microstructural changes in adolescent anorexia nervosa including an exploratory longitudinal study. Neuroimage Clin., 2016, 11: 614-621; DOI: http://dx.doi.org/10.1016/ j.nicl.2016.04.002.

6. Bang L., Rø Ø., Endestad T. Normal gray matter volumes in women recovered from anorexia nervosa: a voxel-based morphometry study. BMC Psychiatry, 2016, 16: 1-7; DOI: 10.1186/s12888016-0856-z.

7. Friederich HC., Walther S., Bendszus M., Biller A., Thomann P., Zeigermann S., et al. Grey matter abnormalities within corticolimbic-striatal circuits in acute and weight-restored anorexia nervosa patients. Neuroimage, 2012; 59(2):1106 - 1113; DOI: 10.1016/j.neuroimage.2011.09.042.

8. McCormick LM., Keel PK., Brumm MC., Bowers W., Swayze V., Andersen A., et al. Implications of starvation-induced change in right dorsal anterior cingulate volume in anorexia nervosa. Int J Eat Disord, 2008; 41(7):602 - 610; DOI: 10.1002/eat.20549.

9. Kaye W.H., Wierenga C.E., Bailer U.F., Simmons A.N., BischoffGrethe A. Nothing tastes as good as skinny feels: the neurobiology of anorexia nervosa. Trends Neurosci, 2013; 36: 110-120; DOI: 10.1016/j.tins.2013.01.003

10. Bang L., et al. Amygdala alterations during an emotional conflict task in women recovered from anorexia nervosa. Psychiatry Res., 2016; 248: 126 - 133; DOI: 10.1016/j.pscychresns.2015.12.008

11. Steinglass J. E., Walsh B. T. Neurobiological model of the persistence of anorexia nervosa. J Eat Disord, 2016; 4: 1-7; DOI: 10.1186/s40337-016-0106-2.

12. Watts AG, Boyle CN. The functional architecture of dehydrationanorexia. Physiology \& behavior. 2010;100(5):472-477. doi:10.1016/j.physbeh.2010.04.010.

13. Reyes-Haro D., Labrada-Moncada F.E., Varman D.R., Krüger J., Morales T., Miledi R., Martínez-Torres A. Anorexia Reduces GFAP+ Cell Density in the Rat Hippocampus. Neural Plast. 2016; 2016: 2426413. doi: 10.1155/2016/2426413.

14. Cerasa A., Castiglioni I., Salvatore C., et al. Biomarkers of Eating Disorders Using Support Vector Machine Analysis of Structural Neuroimaging Data: Preliminary Results. Behav Neurol., 2015; 2015:924814; DOI: http://10.1155/2015/924814.

15. Phillips K.E., Jimerson D.C., Pillai A., Wolfe B.E. Plasma BDNF levels following weight recovery in anorexia nervosa. Physiol Behav. 2016; 165: 300-303. doi: 10.1016/j.physbeh.2016.08.014.

16. Nagamitsu S., Sakurai R., Matsuoka M., Chiba H, Ozono S.,
Tanigawa H., Yamashita Y., Kaida H., Ishibashi M., Kakuma T., Croarkin PE., Matsuishi T. Altered SPECT (123)I-iomazenil Binding in the Cingulate Cortex of Children with Anorexia Nervosa. Front. Psychiatry, 2016; 7: 16; DOI: 10.3389/fpsyt.2016.00016.

17. Clarke J., et al. Higher Reward Value of Starvation Imagery in Anorexia Nervosa and Association with the Val66Met BDNF Polymorphism. Transl. Psychiatry, 2016; 6(6):e829; DOI: 10.1038/tp.2016.98.

18. Park RJ, Godier LR, Cowdrey FA. Hungry for reward: how can neuroscience inform the development of treatment for Anorexia Nervosa? Behav Res Ther 2014; 62 :47 - 59.

19. Keating C. Theoretical perspective on anorexia nervosa: the con $\mathrm{fl}$ ict of reward. Neurosci Biobehav Rev 2010; 34 : 73 - 79.

20. Bartholdy S., McClelland J., Kekic M., O'Daly O. G., Campbell I. C., Werthmann J., Rennalls S. J., Rubia K., David A. S., Glennon D., Kern N., Schmidt U. Clinical outcomes and neural correlates of 20 sessions of repetitive transcranial magnetic stimulation in severe and enduring anor exia nervosa (the TIARA study): study protocol for a randomised controlled feasibility trial. Trials, 2015;16:113;DOI:10.1186/s13063-015-1069-3.

21. Godier L.R., Scaife J.C., Braeutigam S., Park R.J. Enhanced Early Neuronal Processing of Food Pictures in Anorexia Nervosa: A Magnetoencephalography Study. Psychiatry J. 2016; 2016: 1795901. doi: 10.1155/2016/1795901.

22. Phillipou A., Rossell SL., Gurvich C., Hughes ME., Castle DJ., et al. Saccadic Eye Movements in Anorexia Nervosa. PLoS ONE, 2016; 11(3): e0152338; DOI: 10.1371/journal.pone.0152338.

23. Brockmeyer T., Walther S., Ingenerf K., Wild B., Hartmann M., Weisbrod M., Weber M.A., Eckhardt-Henn A., Herzog W., Friederich H.C. Brain effects of computer-assisted cognitive remediation therapy in anorexia nervosa: A pilot fMRI study. Psychiatry Res. 2016; 249: 52-56. doi: 10.1016/j.pscychresns.2016.02.007.

24. Mack I., Cuntz U., Grämer C., et al. Weight gain in anorexia nervosa does not ameliorate the faecal microbiota, branched chain fatty acid profiles, and gastrointestinal complaints. Sci Rep, 2016; 6: 26752; DOI: 10.1038/srep26752.

25. Collins S. M., Surette M., Bercik P. The interplay between the intestinal microbiota and the brain. Nat Rev Microbiol, 2013; 10 : 735-742; DOI: 10.1038/nrmicro2876.

26. Achamrah N., et al. Maintaining physical activity during refeeding improves body composition, intestinal hyperpermeability and behavior in anorectic mice. Sci. Rep., 2016; 6:21887; DOI: 10.1038/srep21887.

27. Morris J.A., et al. Microbes, molecular mimicry and molecules of mood and motivation. Med. Hypotheses, 2016; 87: 40 - 43; DOI: 10.1016/j.mehy.2015.12.011.

28. Teixeira A.L., Junho B.T., Barros J.L., Gomez R.S. Anorexia nervosa presenting as a subacute sensory-motor axonal polyneuropathy. Rev. Bras. Psiquiatr., 2016; 38(2): $180 . \quad$ DOI: https://dx.doi.org/10.1590/1516-4446-2015-1846.

29. Basser P.J, Pajevic S., Pierpaoli C., Duda J., Aldroubi A. In vivo fiber tractography using DT-MRI data. Magn Reson Med 2000; 44(4): 625-632

30. Melhem E.R., Mori S., Mukundan G., Kraut M.A., Pomper M.G., van Zijl P.C. Diffusion tensor MR imaging of the brain and white matter tractography. AJR Am J Roentgenol. 2002; 178(1): 3-16

31. Watts, R.; Liston, C.; Niogi, S.; Ulug, A.M. Fiber tracking using magnetic resonance diffusion tensor imaging and its applications to human brain development.Ment-Retard-Dev-Disabil-Res-Rev.; 2003 9(3): 168-177 
32. Barker A.T., Jalinous R., Freeston I.L. Non-invasive magnetic stimulation of human motor cortex. Lancet 1985; 1(8437): 11061107.

33. Fitzgerald P.B., Fountain S., Daskalakis Z.J. A comprehensive review of the effects of rTMS on motor cortical excitability and inhibition. Clin. Neurophysiol. 2006; 117: 2584-2596.

34. Siebner H.R., Rothwell J. Transcranial magnetic stimulation: new insights into representational cortical plasticity. Exp. Brain Res. 2003; 148(1): 1-16.

35. George M.S., Post R.M. Daily left prefrontal repetitive transcranial magnetic stimulation for acute treatment of medication-resistant depression. Am. J. Psychiatry 2011; 168(4): 356-364.

\section{Correspondence address}

Marcin Olajossy, II Department of Psychiatry and Psychiatric Rehabilitation, Medical University of Lublin,

ul . Głuska 1, 20-439 Lublin, tel. +48 817440967

Otrzymano: 20.09.2016

Zrecenzowano:10.10.2016, 02.11.2016, 28.11.2016

Przyjęto do druku: 01.12.2017 